\title{
The Effectiveness of Social Competence Training based on Felner Model on Communication Skills and Social Adjustment of Nurses in the Psychiatric ward of Selected Hospitals of AJA
}

\author{
Laktarash. $\mathrm{M}^{1}$ \\ ${ }^{*}$ Kalrozi. F2 \\ Pishgooie. $\mathrm{SAH}^{3}$ \\ 1- Msc of Psychiatric Nursing \\ Student, Faculty of Nursing, \\ Aja University of Medical \\ Sciences, Tehran, Iran. \\ 2- ( ${ }^{*}$ Corresponding Author) \\ Ph.D., Student of Nursing, \\ Pediatric Nursing Department, \\ Faculty of Nursing, Aja \\ University of Medical Sciences, \\ Tehran, Iran \\ Email: fkalroozi@yahoo.com \\ 3- Ph.D., in Nursing, Associate \\ Professor, Medical-Surgical \\ Department, Aja University of \\ Medical Sciences, Faculty of \\ Nursing, Tehran, Iran.
}

\begin{abstract}
Introduction: Communication skills and social compatibility have long been recognized as an important part of medical and nursing care. Nursing, due to its feature, requires high social compatibility, specially nurses in psychiatric ward whose main responsibilities are to create a relationship based on trust and motivation in patients to participate in the treatment process. In the Fellner Social Competence Model, various components and dimensions of social adequacy are identified and, accordingly, the necessary training is provided for the development of social skills.
\end{abstract}

Objective: The present study aimed to investigate the effectiveness of Social Competence training based on Felner Model on Communication Skills and Social Adjustment of nurses in the psychiatric ward.

Materials and Methods: This study was a quasi-experimental study. Sixty selected nurses in the psychiatric ward of the AJA hospitals (in 2018) were included in the study and equally divided into the experimental and control hospitals. The experimental group was trained in a two-month 10 sessions, each 60 minutes based on Felner Social Competence Model and Barton Communication Skills questionnaire and Bell Social Adjustment questionnaire were used for data collection. Then, data were analyzed based on descriptive and inferential statistics using SPSS 25.

Results: The result of independent and dependent $t$ tests showed that Social Competence training based on Felner Model significantly improved the mean scores of Communication Skills and Social Adjustment after the intervention $(\mathrm{P}<0.05)$. A precise examination of the sub-components of communication skills showed that in all of the sub-components, the scores increased after the intervention but this increase was only significant for the sub-component of listening skills $(\mathrm{P}=0.01)$.

Discussion and Conclusion: Felner Social Competence training is an effective way to improve the Communication Skills and the Social Adjustment of nurses in psychiatric ward. Thus, experts and health professionals can use Felner Social Competence training as an effective way to improve the Communication Skills and the Social Adjustment of their nurses in the psychiatric ward.

Keywords: Communication Skills, Social Adjustment, Social Competence. 


\title{
بررسى تأثير آموزش كفايت اجتماعى مبتنى بر مدل فلنر بر مهارتهاى ارتباطى و ساز كارى

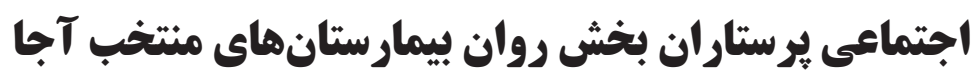

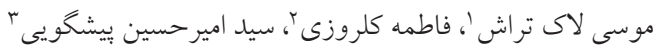

جكکبه

مقدمه: مهارتهاى ارتباطى و سازكارى اجتماعى جزء مههم خدمات يرستارى است؛ و با توجه به اين كه حرفهاى اجتماعى

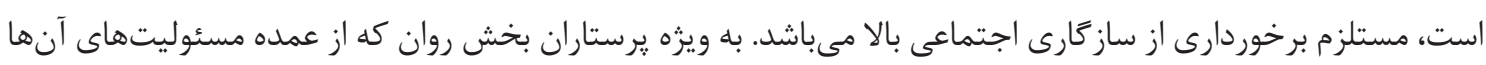

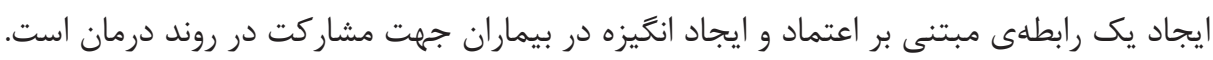

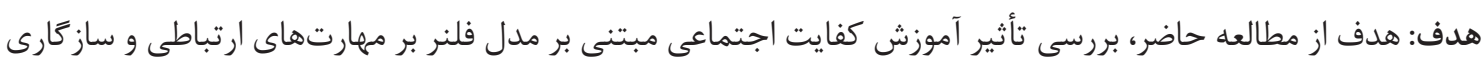
اجتماعى يرستاران بخش روان مىباشد.

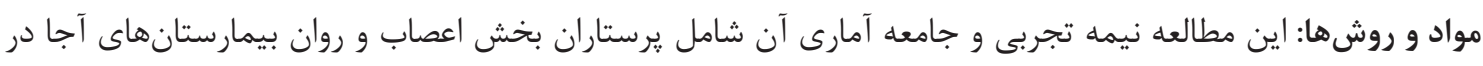

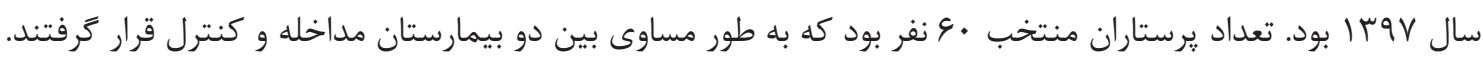

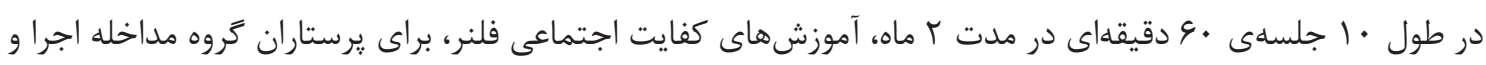

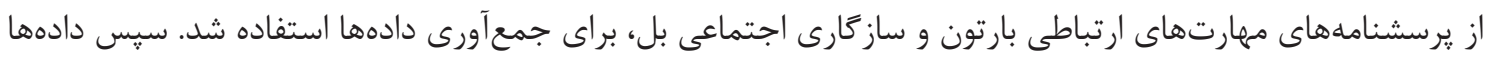

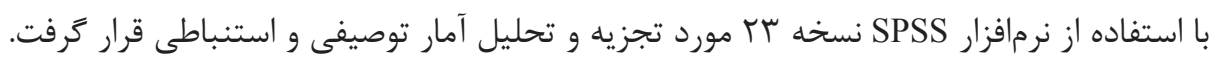

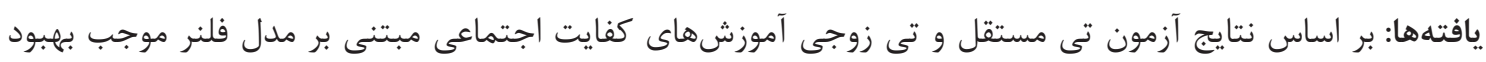

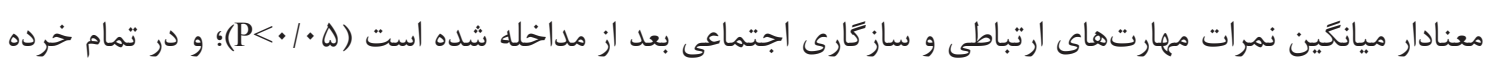

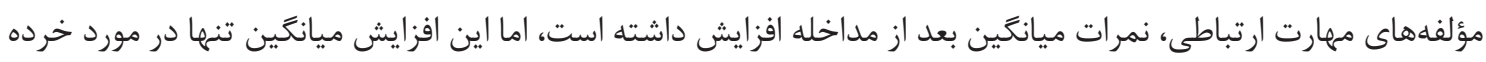

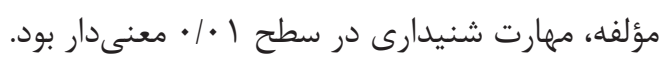

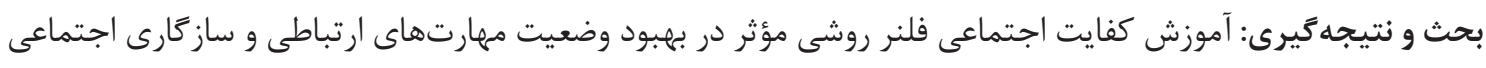

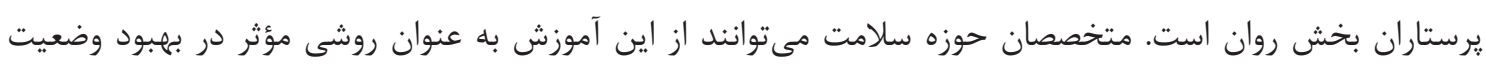

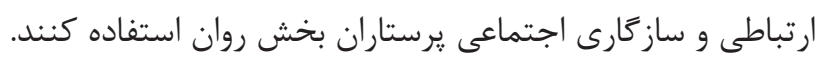

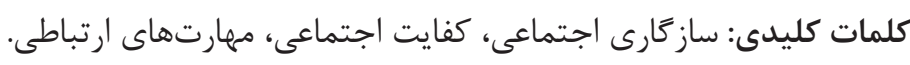

تاريخ دريافت: ت تاريخ:

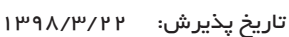

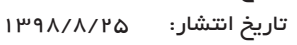

( (1). همه رفتارهاى ما نوعى ارتباط و نيز ارتباطات ما نوعى رفتار مقدمه

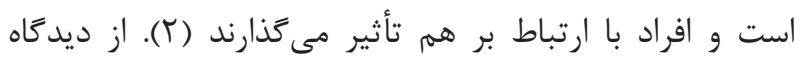
ارتباطات فرايندى است آكاهانه يا نا آكاهانه، خواسته يا نا خواسته محققان، موفقيت سازمانها در گرو مهارتهاى ارتباطى تمام

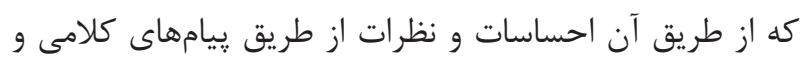

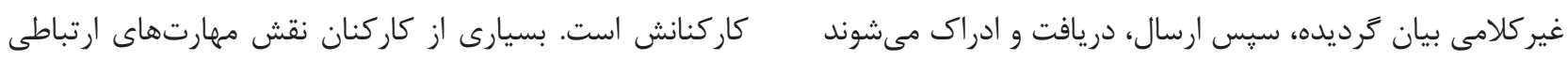


و بتوانند خود را با استرسهاى شغلى سازكار كنند تا بتوانند در

مواقع حساس تصميمات درست اتخاذ كنند (بآ).

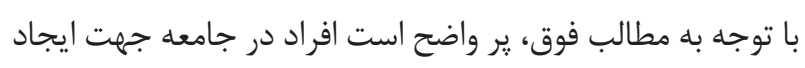

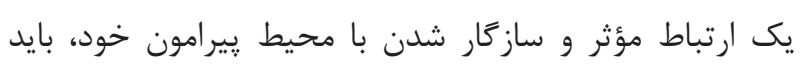

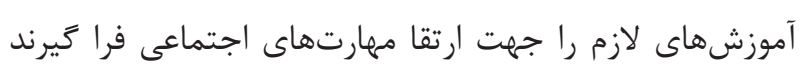

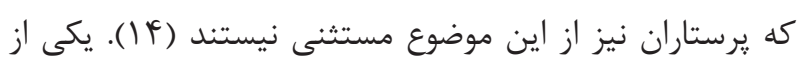

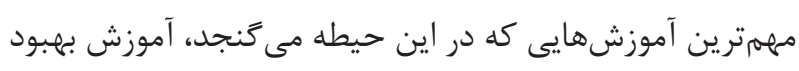

$$
\text { كفايت اجتماعى است (ه) (1). }
$$

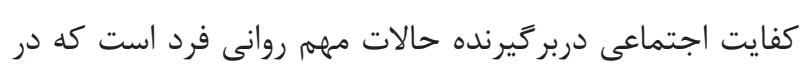
ينج احساس خلاصه مىشود: احساس معنى دار بودن، احساس داس

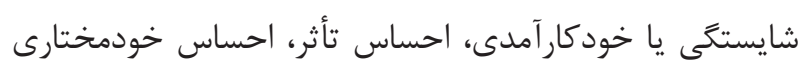

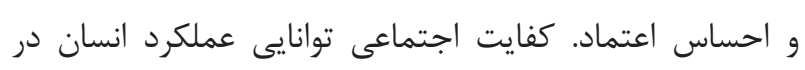

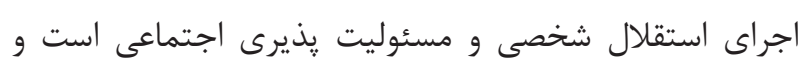

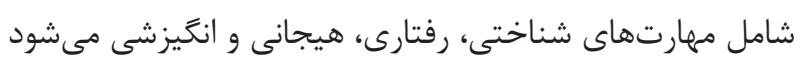

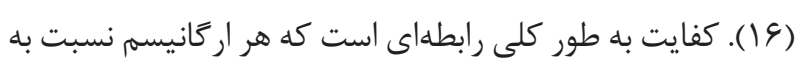

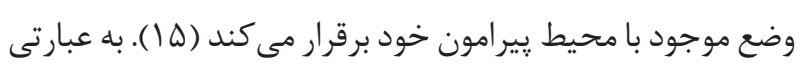

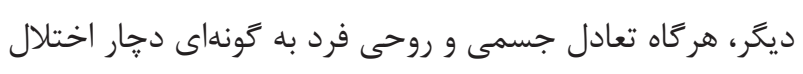
شود كه حالت ناخوشايندى به فرد دست بدهد و براى ايجاد توازن

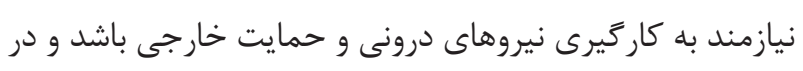

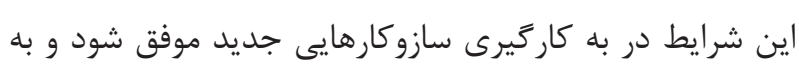

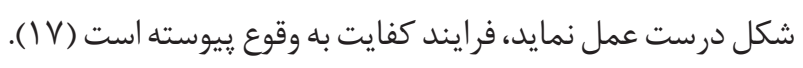

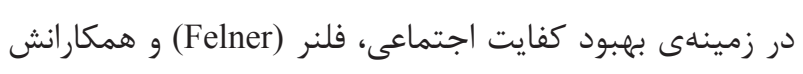
مدلى جامع از كفايت اجتماعى طراحى كردهاند كه داراى جهار

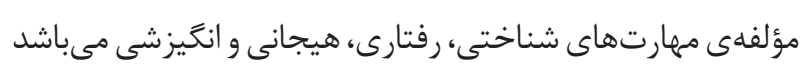

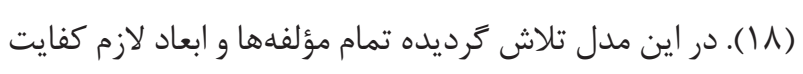

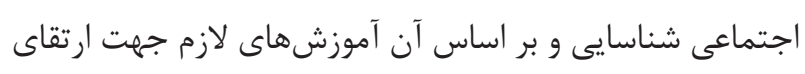

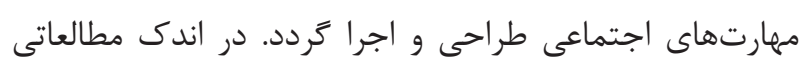

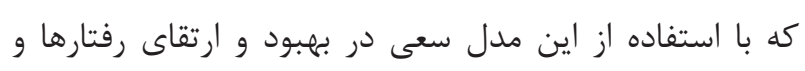

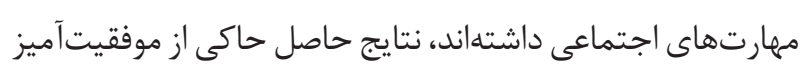

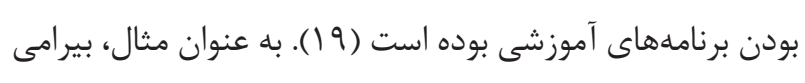
و همكاران در يزوهش خود بر سازكارى اجتماعى دانش آموزان

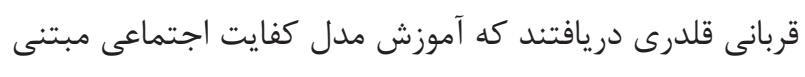

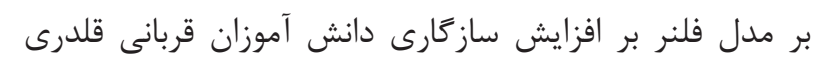
اثربخش است (• (T). در مطالعهاى ديخر، جليل آبكنار و همكاران
را در موفقيت وظايف شغلىشان بسيار مهمتر از مهارتهاى فنى خاص تلقى مى كنند (r). در بين مشاغل نيز يرستارى حرفهاى

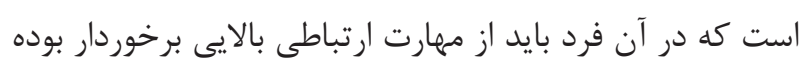

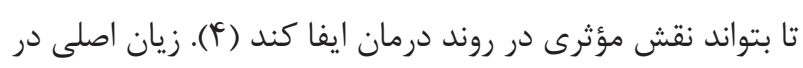

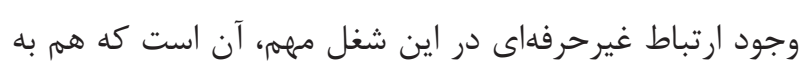

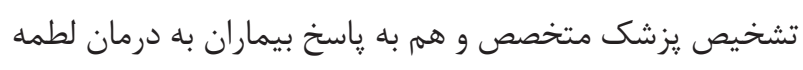

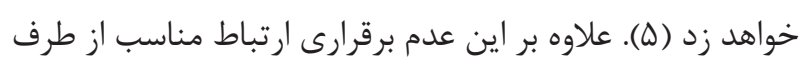

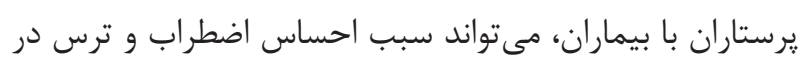

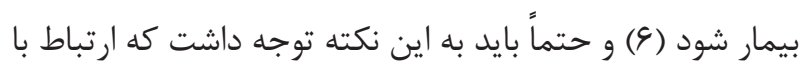
هر فردى منحصر به خود آن فرد است، به ويزه ارتباط با بيماران

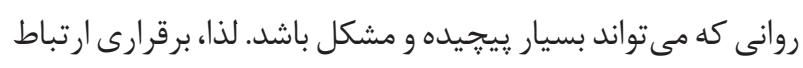

اساس كار حرفهاى يك روان يرستار محسوب مىشود (f) (Y).

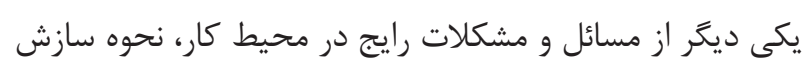

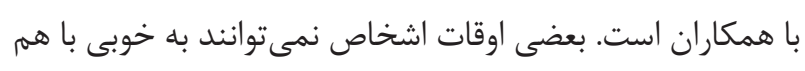

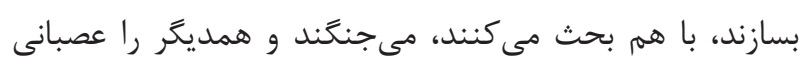

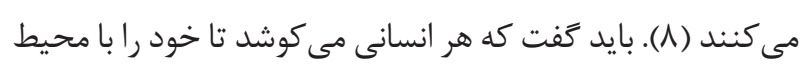

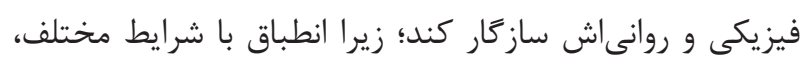

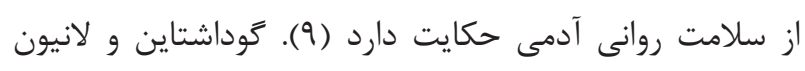
Goodestein and Lanyon) تعريف كردهاند كه در آن، تجارب يادكيرى اجتماعى شخص،

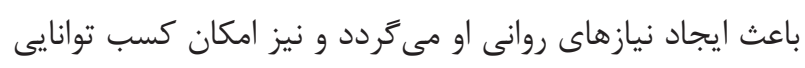

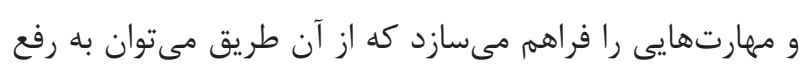

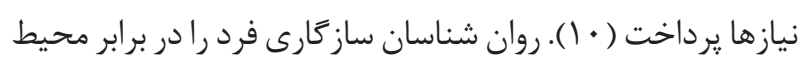

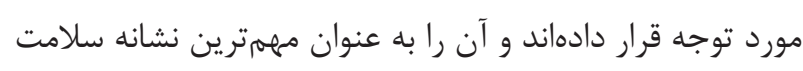

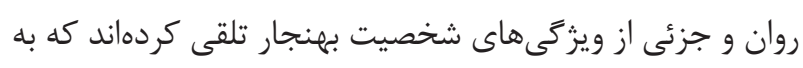

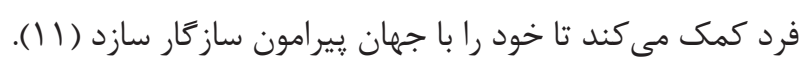

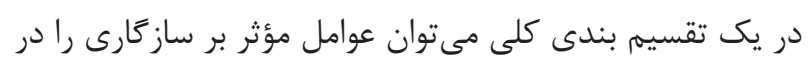

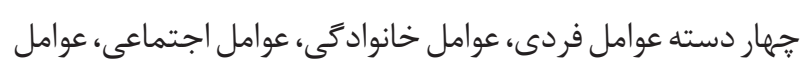
مذهبى و اخلاقى جاى داد (r I ). يرستارى، با توجه به اينكه حرفهاى اجتماعى است، مستلزم

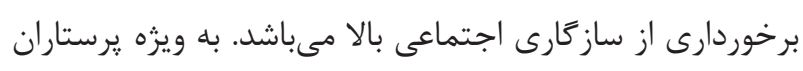

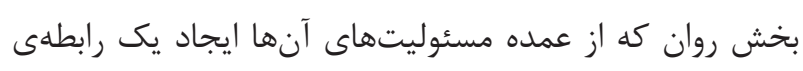

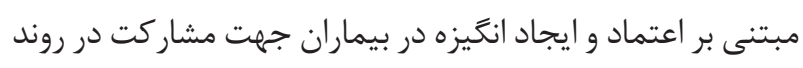
درمان است، مىبايست از سازگارى اجتماعى بالايى برخوردار بوده 
نظر كرفتن ه • • خطاى نوع اول و توان آزمون • • • • و با احتساب

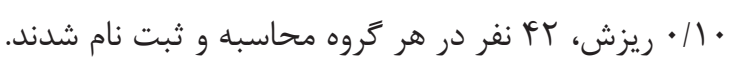

$n=\frac{\left(Z_{1-\frac{\alpha}{r}}+Z_{1-\beta}\right)^{r}\left(s_{1}^{r}+s_{r}^{r}\right)}{\left(\bar{x}_{1}-\bar{x}_{r}\right)^{r}}$

(1) (1ابطه

$n=\frac{r r r / V V \times V / \Lambda \uparrow}{\Lambda \Lambda / r q}=r \Lambda / r q$

يس از خروج تعدادى از افر اد از مطالعه، به دليل انصراف واحدهاى

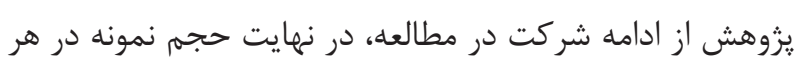

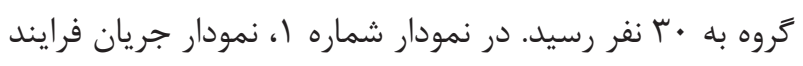

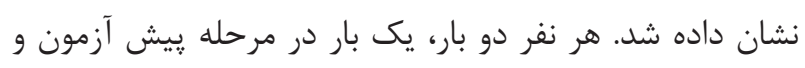

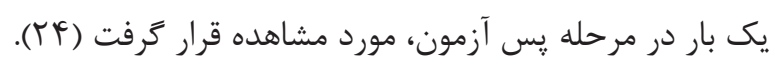

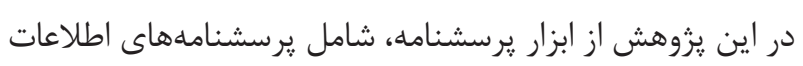

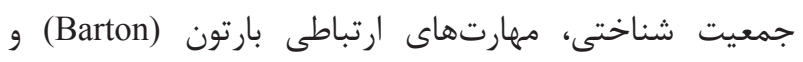

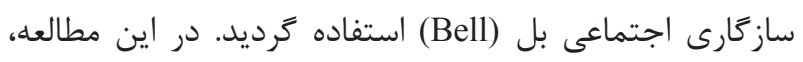

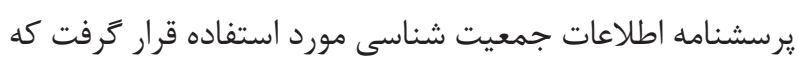
داراى متغيرهايى شامل سن، جنس، تحصيلات، وضعيت تأهل و اشتغال در آن مطرح كرديد. همجنين ازير سشنامه مهارت هاى ارتباطى بار تون (Barton) استفاده

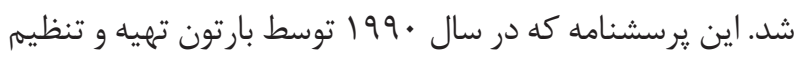
شد، داراى | | آويه بوده و سه مؤلفه مهارت شنيدارى، كلامى و

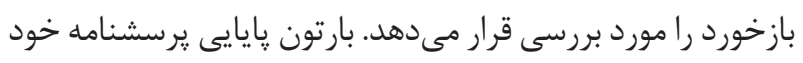

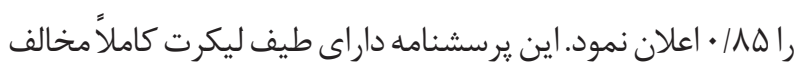

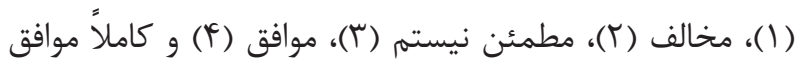

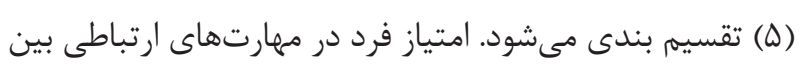

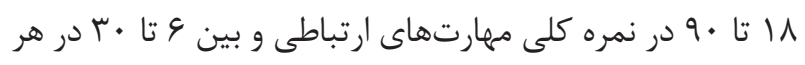

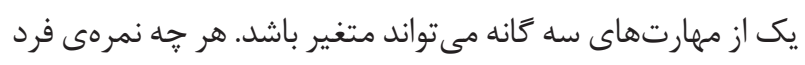
بالاتر باشد، سطح مهارتهاى ارتباطى وى بالاتر است و بالعكس منس

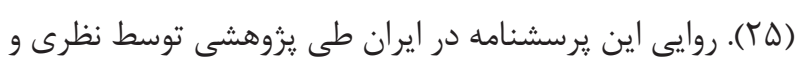

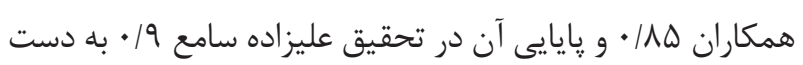

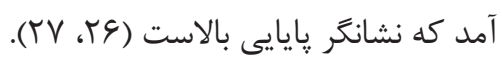

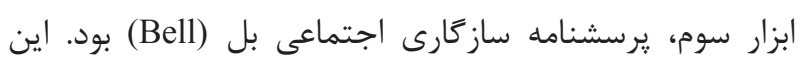

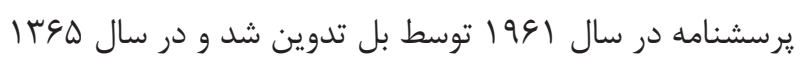

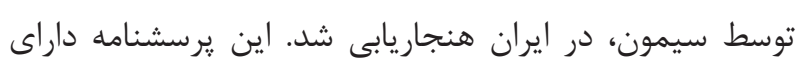

به بررسى اثربخشى آموزش كفايت اجتماعى بر رفتار سازشى دانش

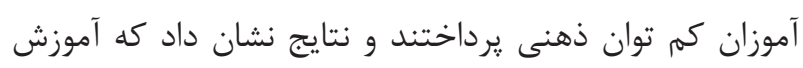

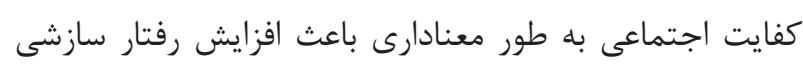

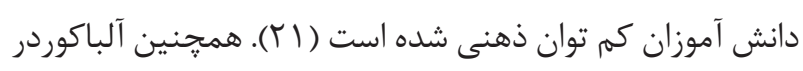
و همكاران در مطالعهاى نشان دادند كه شواهد (Alba Corredor)

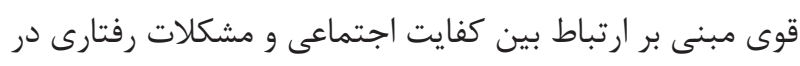

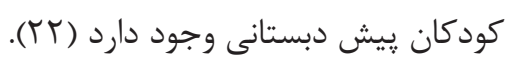
با جمع بندى مطالب بيان شده، اين مطالعه باهدف كلى تعيين تأثير

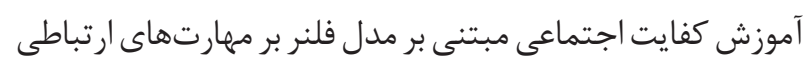

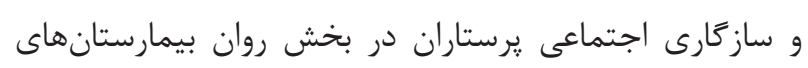

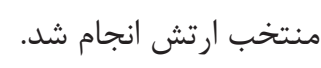

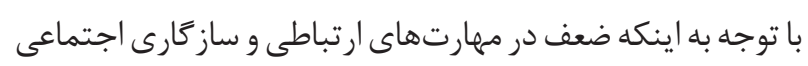

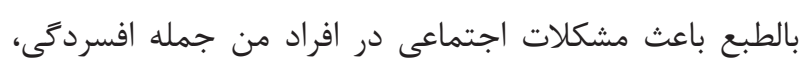

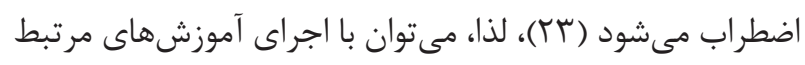
در اين زمينهها، موجب كاهش آثار اجتماعى، بهداشتى و و حتى اجتى إنى

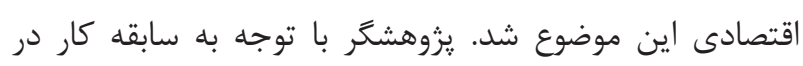
بخشهاى مختلف بيمارستان از جمله بخش روان، به صورت

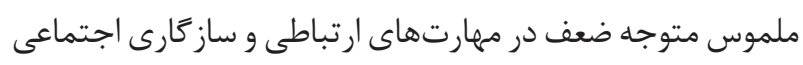
يرستاران شده است.

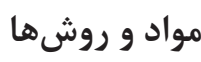

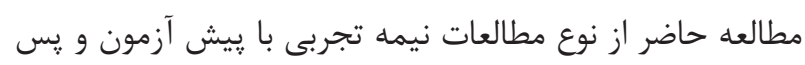

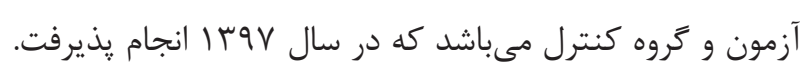

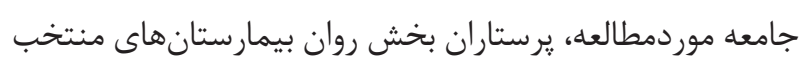

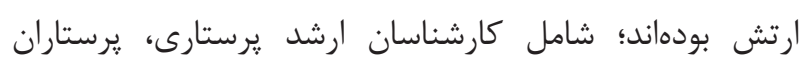
كارشناس كه شرايط ورود به مطالعه را دارا بودند. كليه كارشناسان

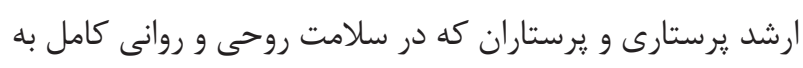

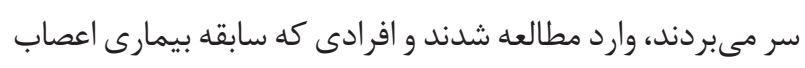

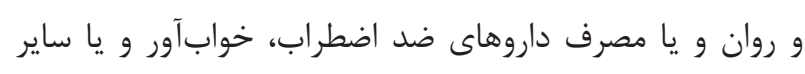
داروهاى اعصاب و روان را داشتند، از مطالعه كنار كذاشته شدند. نمونه گيرى در اين مطالعه به روش نمونه

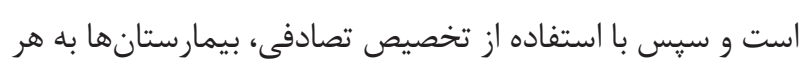

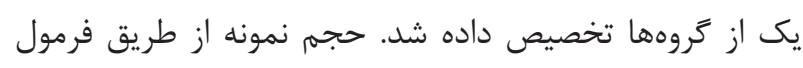

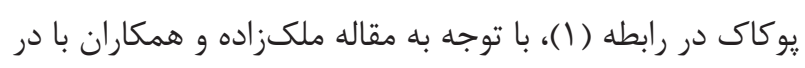



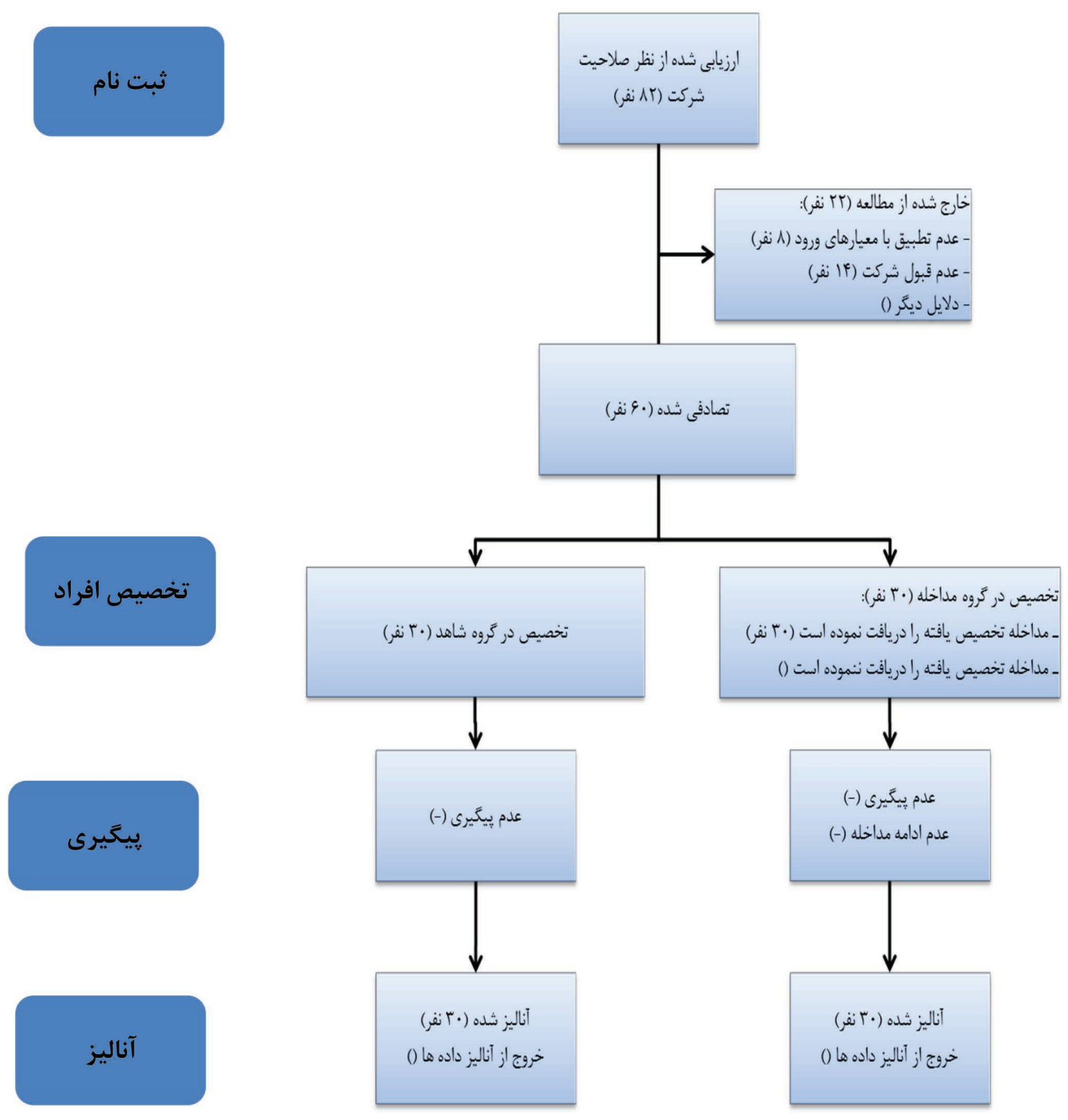

نمودار 1- نمودار جريان فرايند كونسورت

r سؤال است كه هر سؤال از سه كزينه بلى، خير و نمى دانم اجرا شد. يايايى اين آزمون باضريب آلفاى كرونباخ محاسبه كرديد

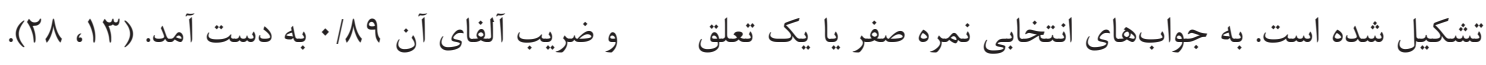

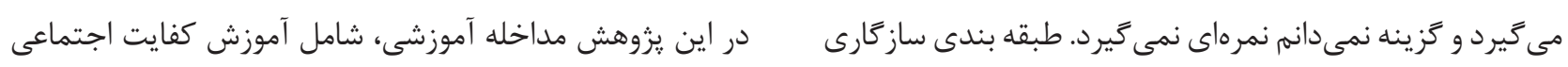

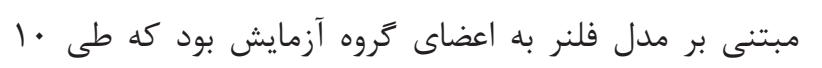

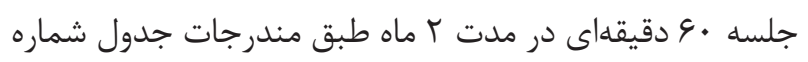

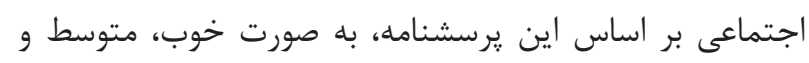

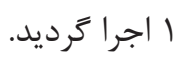

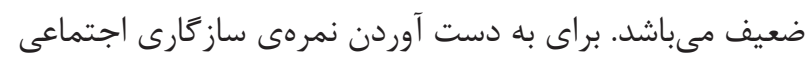

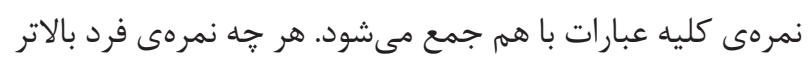
محل بر گزارى كلاسها، سالن آمفى تئاتر بيمارستان بود و با توجه

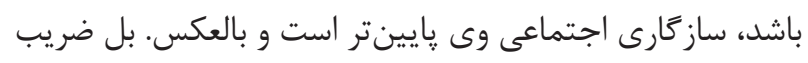
به سوابق كارى يزوهشكر در بخش هاى روان، رشته تحصيلى مرتبط

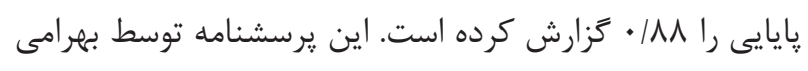

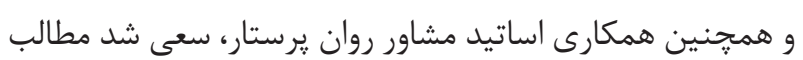

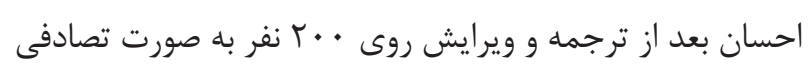


جدول ا- برنامه آموزشى كفايت اجتماعى مبتنى بر مدل فلنر

\begin{tabular}{|c|c|}
\hline فعاليت & جلسه \\
\hline معارفهى گروهى، بيان قوانين گروه، توضيح راجع به مهارتهاى ارتباطى، سازگًارى اجتماعى و اهميت آنها & 1 \\
\hline مهارتهاى بعد شناختى كه شامل تعريف خود ارزشى و عزت نفس، قابليتهاى ادراك صحيح و شناخت خويشتن، اهميت شناخت & $r$ \\
\hline مهارتهاى يردازش و كسب اطلاعات، مهارتهاى تصميمگيرى و جمع بندى مباحث مربوط به حوزهى شناختى & $r$ \\
\hline 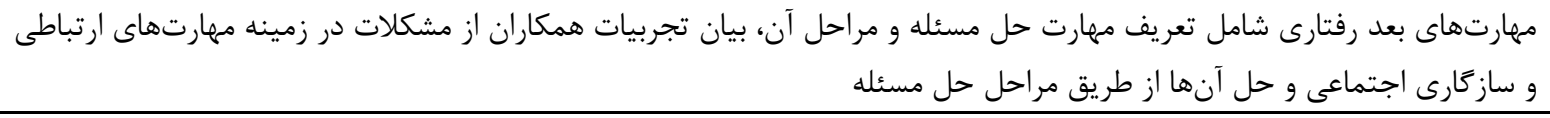 & f \\
\hline مهارتهاى مكالمه، رفتارهاى كمكى فرا اجتماعى، رفتار خود راستين، حوزههاى مهارت و جمعبندى مباحث مربوط به حوزهى رفتارى & $\Delta$ \\
\hline مهارتهاى بعد هيجانى شامل تنظيمم عاطفه، مهارتهاى ارتباطى مؤثر (مانند ايجاد الفت مثبت)، احساسات مربوط به ارزش خود & 9 \\
\hline سندى مبامت ذهنى (رضايت از زندگى)، تعريف استرس و انواع آن، معرفى راهبردهاى مقابله با استرس، آموزش تكنيكهاى آرامسازى و جمع & V \\
\hline مهارتهاى انگيزشى شامل حس خوش بينى يا اميد، رشد اخلاقى و مفهوم كفايت و كنترل & $\wedge$ \\
\hline فر آيندهاى شكل گيرى و حفظ عزت نفس، معيارها و اهداف، ساختار ارزش، مفهوم كاملاً مرتبط خويشتن محتمل و جمعبندى مباحث & 9 \\
\hline جمع بندى نهايى و پياسخ به سؤالات شركت كنندگان در جلسات & 1. \\
\hline
\end{tabular}

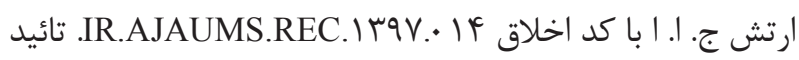
كرديد. ملاحظات اخلاقى بر اساس اصول اساسى بيانيه هلسينكى در خصوص مشاركت كنند گان رعايت شد. اصول نشر (Helsinki) كوب (COPE) نيز رعايت شد. در كليه مراحل مطالعه، جمع آورى (COP و تحليل اطلاعات بدون هيج گونه سوگيرى انجام شد و نتايج يزوهش در صورت درخواست گروه مورد يزوهش، در اختيار آنها

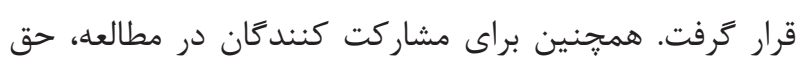
اختيارى بودن شركت در مطالعه در نظر زرفته شد و اطلاعات هويتى آنها حفظ گرديد. تجزيه و تحليل دادهها توسط نرمافزار SPSS نسخه سب با استفاده از آمار توصيفى و استنباطى انجام شد. در زمينه آمار توصيفى از روشهاى آمارى ميانگين و انحراف معيار استفاده شد. در زمينهى آمار استنباطى، از آزمونهاى مقايسه ميانخينها، شامل آزمون مانيان تى مستقل، آزمون كاى مربع و آزمون تى زوجى استفاده شده آزيه است. معيار تصميمگيرى براى معنادارى آزمونها، سطح هـ •/ • در نظر زرفته شد.

بافتهها

يافتههاى جمعيت شناختى يزوهش مندرج در جدول شماره
مفيد در ارتباط با موضوع موردمطالعه در جلسات به نحو مناسب بيان شود. در ضمن جزييات اجراى طرح در اختيار افراد متخصص و اساتيد دانشكده يرستارى قرار زرفت. در جلسات مربوط به حوزه شناختى سعى شد ديدكاه مثبت در افراد نسبت به خود، رويدادها، آينده و به طور كلى زندگى تقويت شود. همجنين در ارتباط با مهارت خودآكاهى كه كمك مى كند تا در مورد خويشتن، نيازها، خصوصيات، اهداف، نقاط ضعف و نقاط قوت، احساسات و هويت خود شناخت كاملترى به دست آورده شود نيز توضيحات لازم داده شد. در حوزه رفتارى نيز مراحل تكنيك مهارت حل مسئله كه مىتواند به فرد كمك كند تا در موقعيتهاى دشوار به تفكر يرداخته و منطقىترين راه حل را براى مقابله با تجارب استرسزاى زندكى بركزيند، نكات آموزشى مرتبط و مورد نياز با ذكر مثال بيان شد. در جلسات حيطه هيجانى نيز آموزشهاى مور نياز در

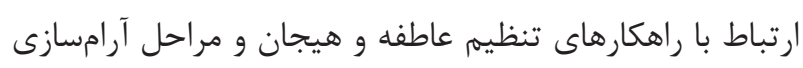
״يش رونده عضلانى جهت الخوى ارتباطى مؤثر داده شد. در حوزه هيجانى نيز سعى شد حس خوشبينى و اميد با تأكيد بر ارائه كارهاى جالب و مهيج و ايجاد اهداف جالش برانتيز و قابل دسترس در شركت كنند كان در جلسات تقويت شود. اين طرح در كميته اخلاق در يزوهش دانشعاه علوم يزشكى دئ دئ 
جدول r - شاخص هاى مربوط به متغير هاى جمعيت شناختى

\begin{tabular}{|c|c|c|c|c|}
\hline \multirow{2}{*}{ آزمون } & \multirow{2}{*}{ درصد (فراوانى) كنترل } & \multirow{2}{*}{ در دروه مداخله } & \multirow{2}{*}{ متغير } & \multirow{5}{*}{ جنس } \\
\hline & & & & \\
\hline \multirow{3}{*}{ 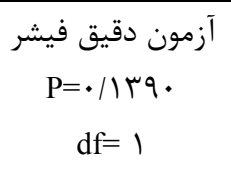 } & $(T \cdot) r T / r$ & $(T r) Y N / r$ & 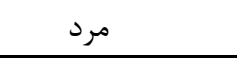 & \\
\hline & $(1 \cdot) 19 / \mathrm{V}$ & (V) $11 / \mathrm{V}$ & زن & \\
\hline & $(\Gamma \cdot) \Delta \cdot$ & $(\Gamma \cdot) \Delta \cdot$ & كل & \\
\hline \multirow{4}{*}{----} & $(\Gamma \cdot) \Delta \cdot$ & $(\Gamma \cdot) \Delta \cdot$ & ليسانس & \multirow{4}{*}{ تحصيلات } \\
\hline & $(\cdot) \cdot$ & $(\cdot) \cdot$ & فوق ليسانس & \\
\hline & $(\cdot) \cdot$ & $(\cdot) \cdot$ & دكترا & \\
\hline & $(\Gamma \cdot) \Delta \cdot$ & $(\Gamma \cdot) \Delta \cdot$ & كل & \\
\hline \multirow{4}{*}{$\begin{array}{c}\text { آزمون دقيق فيشر } \\
\text { P= r }=\text { r I }=r \\
\text { df }\end{array}$} & (Yr) YN/ & (YT) rG/V & نظامى & \multirow{4}{*}{ اشتغال } \\
\hline & (f) $9 / V$ & (^) $1 \% / r$ & غيرنظامى & \\
\hline & (广) $\Delta / \cdot$ & $(\cdot) \cdot / \cdot$ & ساير & \\
\hline & $(\Gamma \cdot) \Delta \cdot$ & $(\Gamma \cdot) \Delta \cdot$ & كل & \\
\hline آزمون دقيق فيشر & $(I V) Y N / r$ & r/r/T & متأهل & \multirow{3}{*}{ 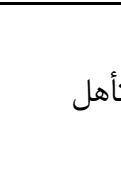 } \\
\hline 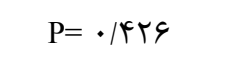 & $(\mid r) \Gamma / / V$ & $(1 \cdot) 19 / \mathrm{V}$ & غيرمتأهل & \\
\hline $\mathrm{df}=1$ & $(\Gamma \cdot) \Delta \cdot$ & $(\Gamma \cdot) \Delta \cdot$ & كل & \\
\hline آزمون تى مستقل & $r M \cdot V$ & $r r / T V$ & ميانكَين & \multirow{3}{*}{ سن } \\
\hline $\mathrm{P}=\cdot / \mathrm{\wedge} \mathrm{r}$ & $F / V I$ & $V / \Delta \Delta$ & انحراف معيار & \\
\hline $\mathrm{df}=\boldsymbol{\uparrow} \wedge / \xi \cdot \Lambda$ & $r$. & $r$. & تعداد & \\
\hline
\end{tabular}

با يكديخر همخن هستند.

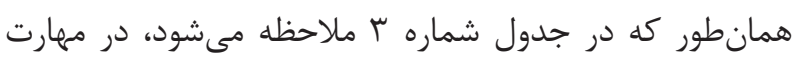

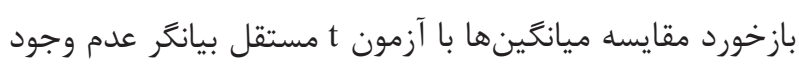

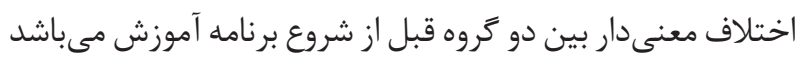

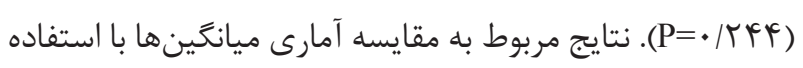

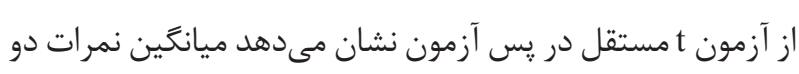

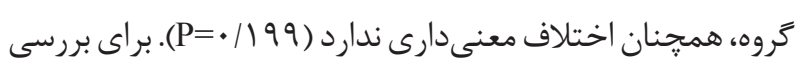

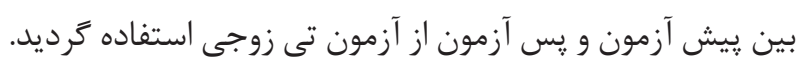

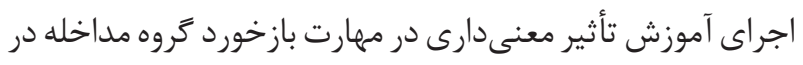

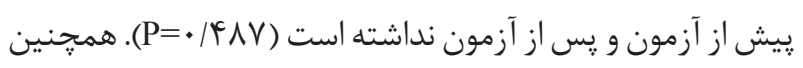

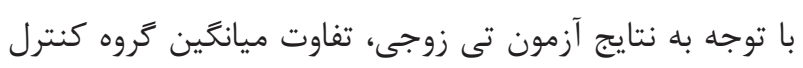

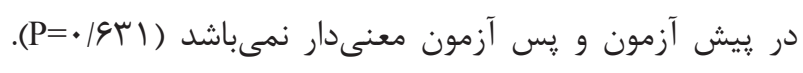

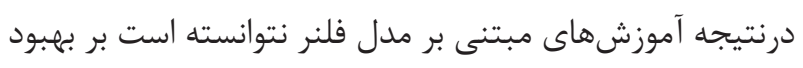

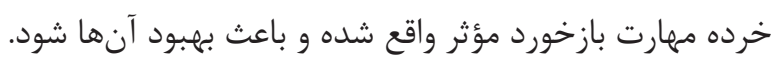
$|r|$ براى متغير مهارت شنودى، نتايج به دست آمده از آزمون تى بـ بـ زوجى مندرج در جدول شماره ب حاكى از وجود تفاوت معنى دار
نشان مىدهد كه واحدهاى مورد يزوهش در دو گروه مداخله و

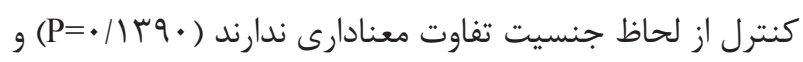

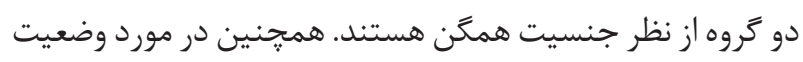

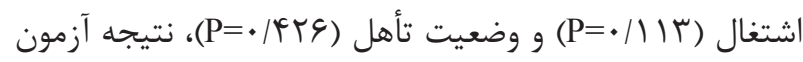
دقيق فيشر نشان مىدهد كه دو گروه مداخله و كنترل اخلاف

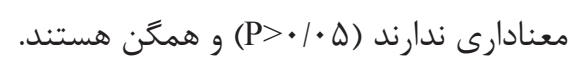

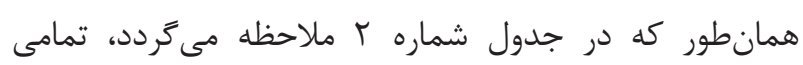

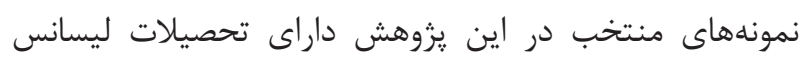

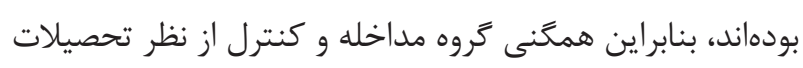

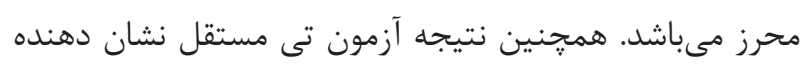

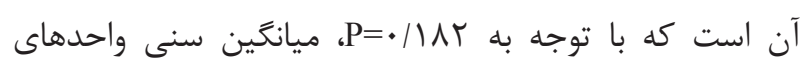

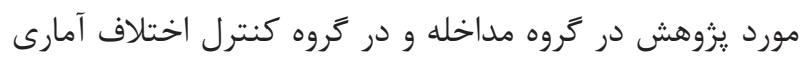
معنى دارى ندارند. در مجموع، آزمونهاى آمارى نشان مى ندهد بين كروه آزمايش و

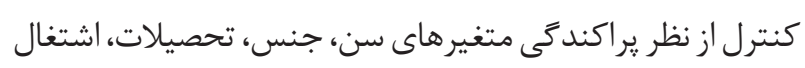

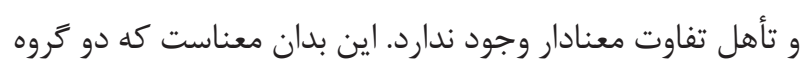


جدول بـ - نتايج آزمون تى مربوط به َّروه و زمان آزمون در مهارتهاى ارتباطى و سازَارى اجتماعى

\begin{tabular}{|c|c|c|c|c|}
\hline $\begin{array}{c}\text { آزمون تى زوجى } \\
\text { P-value }\end{array}$ & يس آزمون & ييش آزمون & ت تروه & متغير \\
\hline 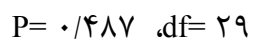 & $r T / Q V \pm T / / F$ & $r T / \cdot V \pm V / F q$ & مداخله & \multirow{3}{*}{ مهارت بازخورد } \\
\hline \multirow[t]{2}{*}{$\mathrm{P}=\cdot|q \mathrm{r}| \cdot \mathrm{df}=r q$} & $r / / \cdots \pm N / \cdot 1$ & $r \cdot r \mu \pm r / \cdot 1$ & كنترل & \\
\hline & $\begin{array}{c}P=\cdot / 199 \\
d f=\Delta \Lambda\end{array}$ & 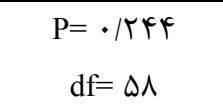 & آزمون تى مستقل & \\
\hline $\mathrm{P}=\cdot / \cdots \cdot \mathrm{df}=r q$ & $r \cdot / r \cdot \pm r / q r$ & $\mid Q / r V \pm r / \Lambda$. & مداخله & \multirow{3}{*}{ مهارت شنيدارى } \\
\hline $\mathrm{P}=\cdot / \cdots \cdot \mathrm{df}=r_{q}$ & $|N / F V \pm T / V|$ & $\mid \mathrm{V} / \cdots \pm f / \cdot q$ & كنترل & \\
\hline & $\begin{array}{c}\mathrm{P}=\cdot / \cdot r \mathrm{f} \\
\mathrm{df}=\Delta \Lambda\end{array}$ & $\begin{array}{c}\mathrm{P}=\cdot / / 1 \mu \\
\mathrm{df}=\Delta \Lambda\end{array}$ & آزمون تى مستقل & \\
\hline $\mathrm{P}=\cdot / r \wedge \cdot d \mathrm{df}=r q$ & $r T / q V \pm F / F \wedge$ & $r r / \cdot V \pm r / r \Lambda$ & مداخله & \multirow{3}{*}{ مهارت كلامى } \\
\hline $\mathrm{P}=\cdot|\Delta| \mid d \mathrm{df}=r q$ & $r \cdot / \cdot r \pm r / l l$ & $r \cdot / r V \pm 1 / 9$. & كنترل & \\
\hline & $\begin{array}{c}P=\cdot / \cdot r \\
d f=\Delta \Lambda\end{array}$ & $\begin{array}{c}\mathrm{P}=\cdot / \cdot 1 \Lambda \\
\mathrm{df}=\uparrow \varepsilon / \Delta r \Delta\end{array}$ & آزمون تى مستقل & \\
\hline$P=\cdot / \cdot r \cdot d f=r q$ & $\varphi q / 11 \pm V / .9$ & $\Delta 9 / \Delta \cdot \pm 11 / 1$. & مداخله & \multirow{3}{*}{ مهارتهاى ارتباطى } \\
\hline \multirow[t]{2}{*}{$\mathrm{P}=\cdot / r \mid \Delta \cdot \mathrm{df}=r q$} & $\Delta 9 / \Delta \cdot \pm \Lambda / 9 \vee$ & $\Delta V / V \cdot \pm r / q 1$ & كنترل & \\
\hline & $\begin{array}{c}P=\cdot / \cdot r \\
d f=\Delta \Lambda\end{array}$ & $\begin{array}{c}P=\cdot / \uparrow \cdot \wedge \\
d f=r \xi / \cdot ৭ \Lambda\end{array}$ & آزمون تى مستقل & \\
\hline$P=\cdot 1 \cdot \bullet \cdot d \mathrm{df}=r q$ & $\Lambda / F T \pm \Delta / V \mu$ & $\mid r / \Lambda \cdot \pm V / \cdot \Lambda$ & مداخله & \multirow{3}{*}{ سازحًارى اجتماعى } \\
\hline \multirow[t]{2}{*}{$\mathrm{P}=\cdot / r \cdot \Delta \cdot \mathrm{df}=r q$} & $I T / V V \pm r \cdot 1 \cdot q$ & $9 / 9 \vee \pm r / T q$ & كنترل & \\
\hline & $\begin{array}{c}\mathrm{P}=\cdot / \Upsilon \xi \mid \\
\mathrm{df}=\Delta \Lambda\end{array}$ & $\begin{array}{c}\mathrm{P}=\cdot / \cdot 94 \\
\mathrm{df}=\mathrm{FV} / \Delta 9 r\end{array}$ & آزمون تى مستقل & \\
\hline
\end{tabular}

در نمره كل مهارت هاى ارتباطى، مقايسه ميانخينها با آزمون تى

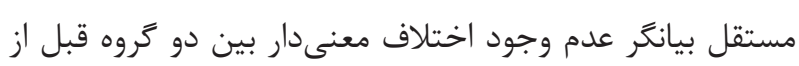

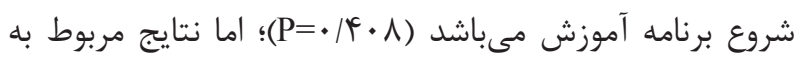
يس آزمون نشان مىدهد ميانخين مهارتهاى ارتباطى در هر دو

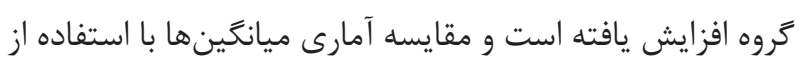
آزمون تى مستقل نشان مىدهد ميانگين نمرات دو گروه، اختلاف

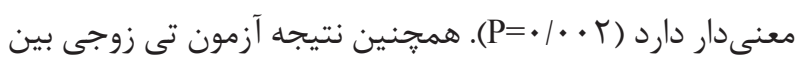
ييش آزمون و پِ آزمون در گروه مداخله نشان مىدهد اجراى

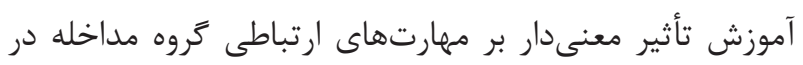

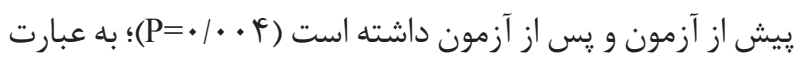
ديخر آموزش مبتنى بر مدل كفايت اجتماعى فلنر موجب بهبود مهارتهاى ارتباطى يرستاران شده است. مقايسه ميانخين هاى سازَّارى اجتماعى در زروه مداخله در مرحله ييش آزمون و يس آزمون نشان ميدهد كه يس از آموزش مدل

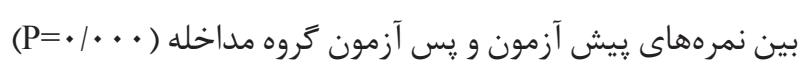

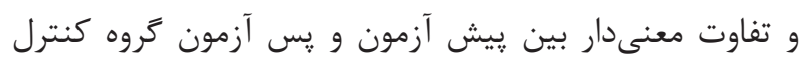

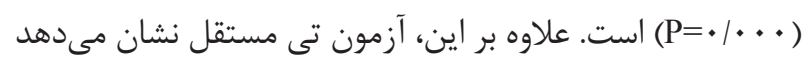
ميانگين نمرات گروه مداخله در يس آزمون، به شكل معنى ردارى

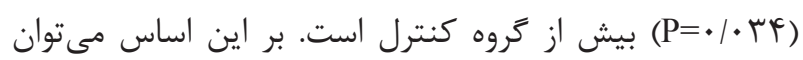
نتيجه گرفت آموزش مدل كفايت اجتماعى مبتنى بر مدل فلنر موجب افزايش مهارت شنودى در يرستاران بخش روان شده است. در مهارت كلامى، نتايج آزمون تى زوجى نشان مىدهد اجراى آموزش تأثير معنى دار در مهارت كلامى گروه مداخله در يِيش از

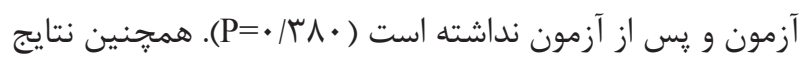
آزمون تى زوجى نشان مىدهد تفاوت ميانگين مهارت كلامى آنى كروه كنترل در يِيش آزمون و يس آزمون معنى

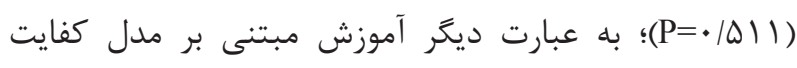
اجتماعى فلنر موجب بهبود خرده مهارت كلامى نشده است. 
و استفاده مؤثر از آنها باعث مهار و نظم دهى به هيجانات و احساسات مىشود كه نقش مهمى در تداوم و سلامت روابط ايفا

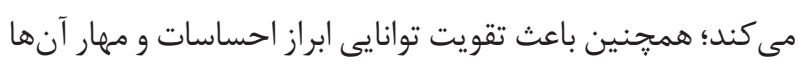

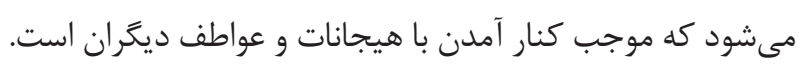

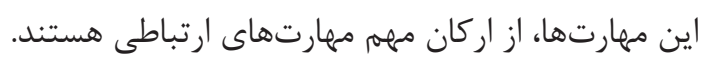

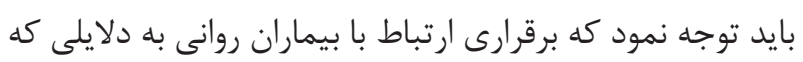

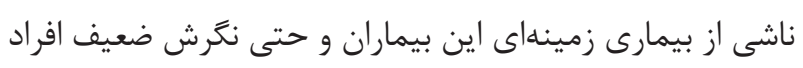

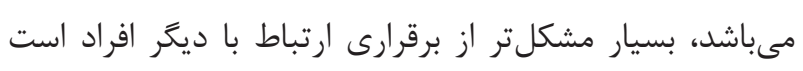

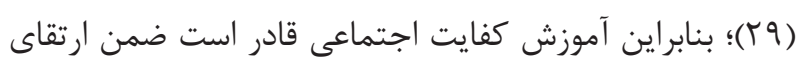

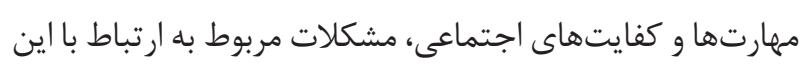
بيماران را كاهش دهد.

يافتههاى ديخر اين مطالعه، نشان مى دهد كه پِ إن از آموزش كفايت

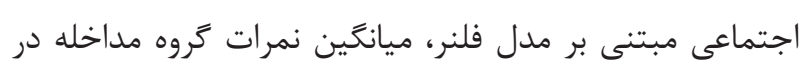

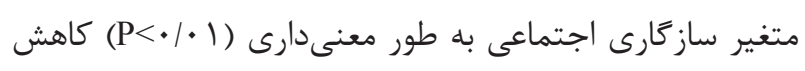

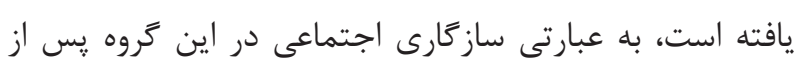
دريافت آموزش، افزايش يافته است. مى توان كفت ائن اين يافته با نتايج

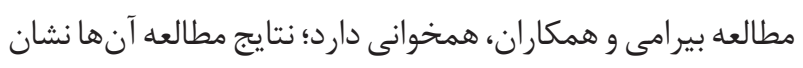

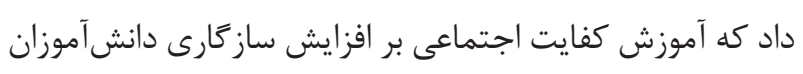

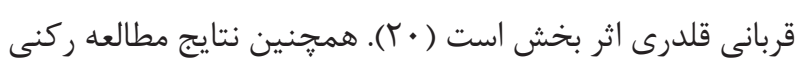

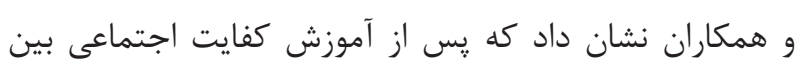

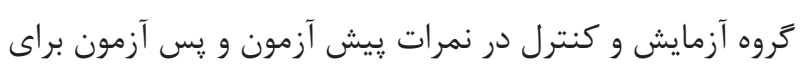

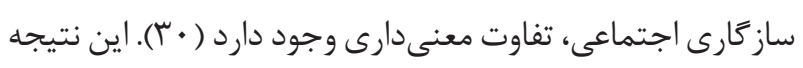

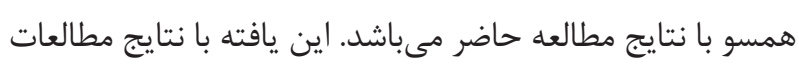

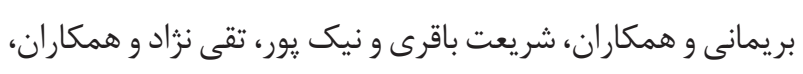

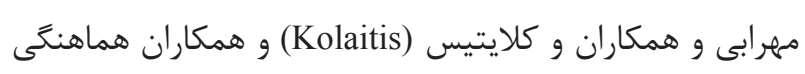

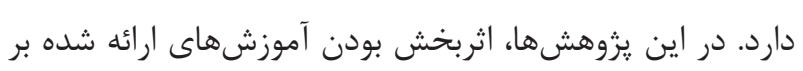
سازگًارى اجتماعى تائيد شده است.

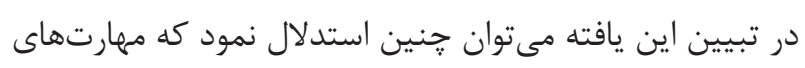

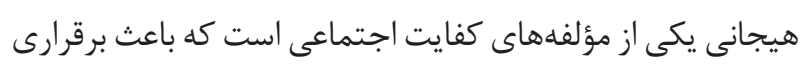

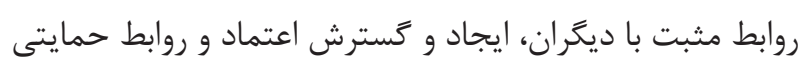
دو طرفه، شناسايى و ياسخدهى مناسب به علائم هيجانى در روابط

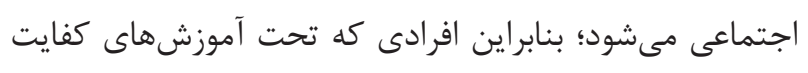

كفايت اجتماعى مبتنى بر مدل فلنر، ميانكين نمرات در گروه

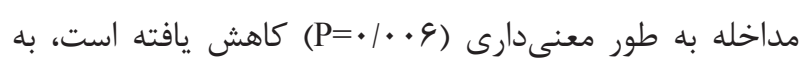

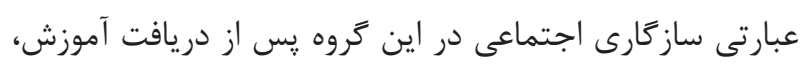

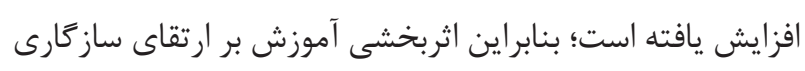
اجتماعى تائيد مىشود.

\section{بحث و نتيجدة مديرى}

هدف از اين مطالعه، تعيين تأثير آموزش كفايت اجتماعى مبتنى ندي بر مدل فلنر بر مهارتهاى ارتباطى و ساز حارى اجتماعى يرستاران

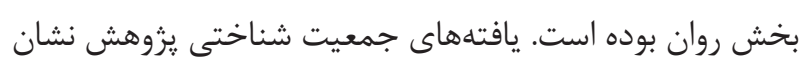

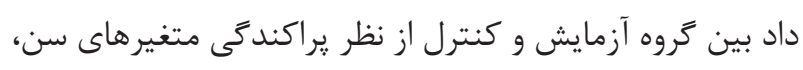

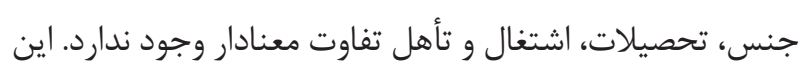

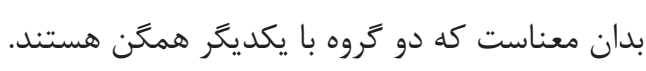

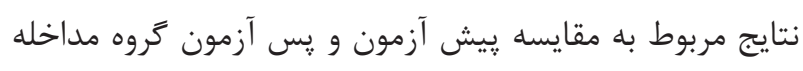

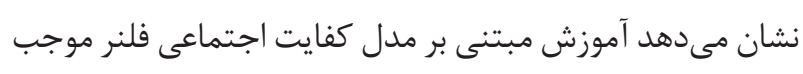

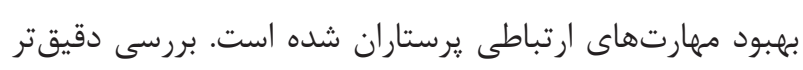

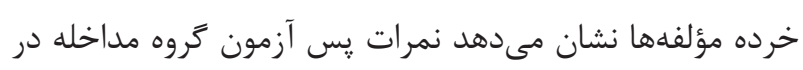

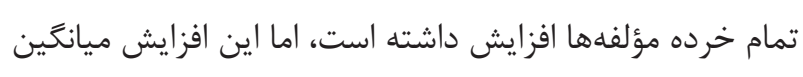

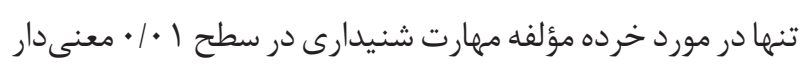
مىباشد. اين يافته با نتايج مطالعه جليل آبكنار و همكاران موردان همخوانى دارد؛ نتايج مطالعه آنها نشان داد كه برنامه آموزشى بإنى

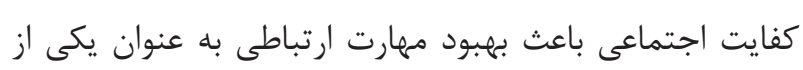

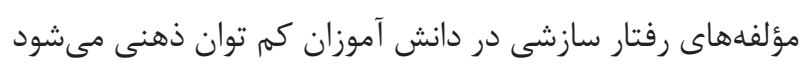

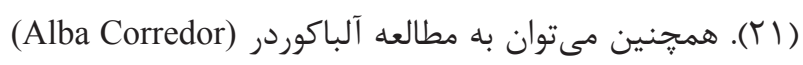

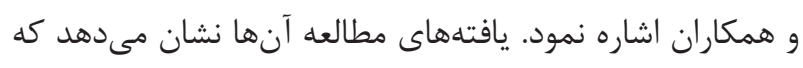
به طور عمده شواهد قوى براى ارتباط بين كفايت اجتماعى و

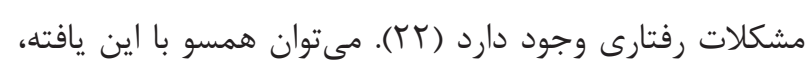

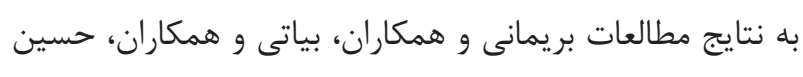

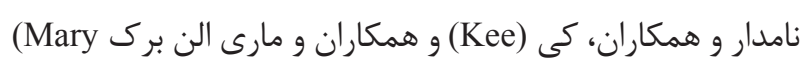
ellen burke) در تبيين اين يافته مىتوان جنين استدلال كرد كه مجموعه

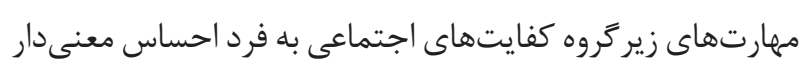

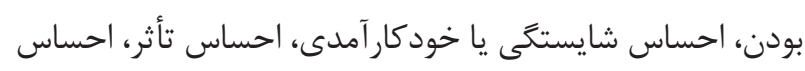

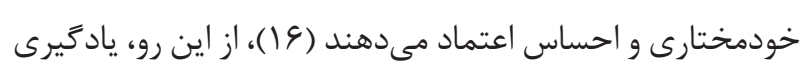


مطالعه، دانش قبلى نمونهها در ارتباط با موضوع تحقيق بوده است. همجنين جامعلى آمارى ڤزوهش شامل كليهى ڤيرستاران بخش روان بوده است، بنابراين تعميمم نتايج حاصل شده به ساير

$$
\text { جوامع آمارى بايد با احتياط صورت كيرد. }
$$

\section{تشكر و قدردانى}

اين مطالعه برگرفته از يايان نامه كارشناسى ارشد رشته روان

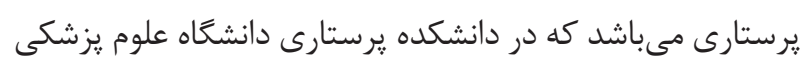

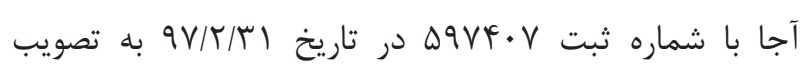

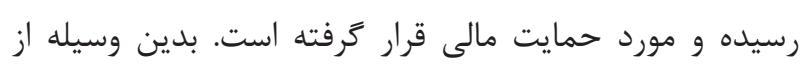
دانشكده يرستارى دانشعاه علوم يزشكى آجا، به عنوان حامى اين يزوهش، صميمانه تقدير و تشكر مىشود. از پرسنل و ״رستاران بيمارستانهاى منتخب نظامى براى همكارى در فرآيند اجراى طرح، كمال تقدير و تشكر به عمل مى آيد.

تضاد منافع

بدين وسيله نويسندگان تصريح مىنمايند كه هيج گونه تضاد منافعى در خصوص تحقيق حاضر وجود ندارد.

\section{References}

1- Berko R, Volvine A, Volvine D. Communicating: A Social And Carea Focus. tehran: Office of Cultural Research, 2014.

2- Ekrami M. Principles of Mass Communication. Mashhad: Bijan Institute, 2003.

3- Pourasghar M, Najafi K, Tirgari A, Yazdani J, Falaki M, Salehi F. Investigating Employees' and Health Care Practitioners' Communication Skills. Iranian $\mathrm{J}$ Psychiatry and Clinical Psychology. 2017;23(2):208-17. DOI: 10.29252/nirp. ijpcp.23.2.208

4- Janati Y, Hosseini S, Azimi lolati H, Mahmoodi Alami G. Mental Health Nursing Tehran: Jamea Negar, 2014.

5- Farhadi Y. Professional Ethics in Mental Health. Tehran: Ettelaat, 2007.

6- Bramhall E. Effective communication skills in nursing practice. Nurs Stand. 2014;29(14):53-9. DOI: 10.7748/ns.29.14.53.e9355 PMID: 25467362

7- Hojjati H. Browse Mental Health Nursing. Tehran: Jamea Negar, 2008.

8- Zarrabi A. From Unhealthy Connections to Healthy Connections.
داشته، از اين رو كاركرد بسنده و مناسبى در اجتماع خواهند داشت؛ كه اين امر از نمودهاى مهمم ساز ₹ار شدن با جامعه است. بر اساس يافتههاى اين مطالعه، آموزش كفايت اجتماعى فلنر روشى مؤثر در بهبود وضعيت مهارتهاى ارتباطى و سازگارى اجتماعى يرستاران بخش روان است. با توجه به يافتههاى مطالعه،

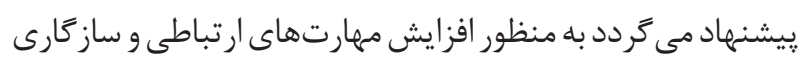
اجتماعى يرستاران، آموزشهاى مدون و طراحى شدهى مدل كفايت اجتماعى، در برنامه آموزش مداوم و آموزش حين خدمت آمونى

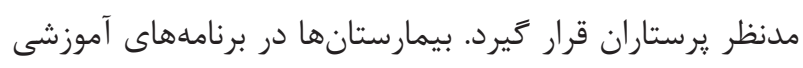

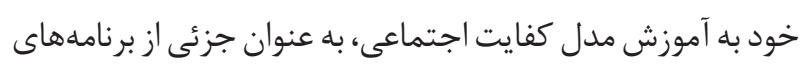

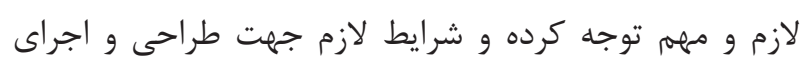
استاندارد كار كاههاى آموزشى كفايت اجتماعى و همجٍنين تدريس اين كار Fاهها توسط مدرسين مجرب و متخصص را فراهم آورند.

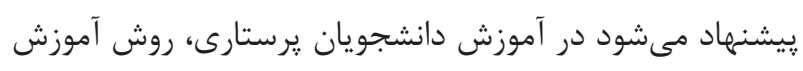
كفايت اجتماعى مورد توجه برنامه ريزان درسى و مدرسين قرار كيرد تا بتوان ڤرستارانى تربيت كرد كه قادر باشند با استفاده از اين مهارتها، موجب ارتقاى سطح سلامت عمومى جامعه گردند.

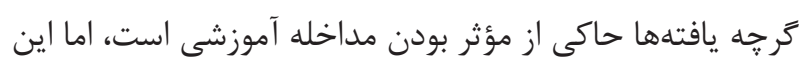
مطالعه محدوديتهايى نيز داشت. يكى از محدوديتهاى اين

Esfahan: Naghshe Mana, 2009.

9- Amani R, Etemadi A. The Relationship Between Attachment Styles and Social Adjustment. Clinical Psy \& Personality, Shahed University. 2010;19(6):15-26.

10- Mazaheri A, Bagheban A, Fatehizadeh M. The Effect of Group Training of Self-Esteem on Students' Social Adjustment Clinical Psy \& Personality, Shahed University. 2006;13(16):49-56.

11- Taghinezhad Z, Eghlima M, Arshi M, Pourhossein Hendabad P. Effectiveness of Social Skills Training on Social Adjustment of Elderly People. Journal of Rehabilitation. 2017;18(3):230-41. DOI: $10.21859 /$ jrehab-1803230

12- Eslami Nasab A. Compatibility Psychology. Tehran: Bonyad, 1994.

13- Bavier B. Mental Health Nursing: Introductory Text Book. Ahvaz: Khaledin; 2008.

14- Bahreini K. Communication and dynamics in the group. Tehran: Mirshida; 2010.

15- Afshar Niyakan S. Evaluation and comparison of social and emotional compatibility in female and female students of 
mathematical. tehran: experimental and Social Sciences. Tehran: Alzahra University; 2002.

16- Ashoori M, Pourmohamadreza-Tajrishi M, Jalil-Abkenar SS, Fallah AM, Azimi Garoosi S. Effectiveness of Mental Immunization Program Training on Social Competency and Personality Traits of Individuals With Cerebral Palsy. Journal of Rehabilitation. 2017;18(2):96-107. DOI: 10.21859/jrehab-180296

17- Eslami Nasab Bojnordi A. Obsessive treatment. Tehran: Shafabakhsh; 2004.

18- Reinke M, Dattilio F, Freeman A. Cognitive therapy with children and adolescents: a casebook for clinical practice. Tehran: Arjmand; 2015.

19- Micaeeli Monie F, Eisazadegan A, Naghavi Harzand M. The Effectiveness of Social Competence Training Based on Fellner's Model on Improving the Growth and Social Skills of Mentally Undressed Girls. Journal of Psychology 2011;6(4):175-202.

20- Bayrami M, Hashemi Nosratabad T, Badri Gargari R, Dabiri S. The Effectiveness of Social Competence Training based on Felner Model on Social Adjustment of Students Being Bullying Victims, with Regards to the Type of Social Goal Orientation. Quarterly Clinical Psychology Studies. 2016;6(23):1-24.

21- Jalilabkenar S, Aashoori M, Pourmohamadreza Tajrishi M. The Effectiveness Social Competence Instruction on the Adaptation Behavior in Male Students with Intellectual Disability. Rehabilitation. 2013;13(5):104-13.

22- Corredor GA, Justicia-Arráez A, Romero-López M, BenavidesNieto A. Longitudinal Study of the Effects of Social Competence on Behavioral Problems. Procedia - Social and Behavioral Sciences. 2017;237:479-85. DOI: 10.1016/j.sbspro.2017.02.093

23- Bolton R. People Skills. Tehran: Roshd; 2011.

24- Malekzadeh J, Amoozeshi Z, Mazloom S. The Effect of Teaching Orem Self- Care Model on Nursing Students Communication Performance in Clinical Setting.. Modern Care Scientific Quarterly of Birjand Nursing and Midwifery Faculty. 2011;8(3):107-13.

25- Alizadeh Samea M. The Relationship between Communication Skills of Managers and the Morale of High School Teachers in Maragheh. Azad University. 2008.

26- Nazari R, Tahani M. The Relationship between Creativity and Communication Skills in Sport Manages. Communication Management in Sports Media. 2014;2(5):51-8.

27- Rezaeyan A. Management of Organizational Behavior. Tehran: Faculty of Management of Tehran University 1995.

28- Aalipoor Birgani S, Eshaghi H, Jelodari A. The Relationship between Perceived Social Support and Academic Self-Efficacy with Social Adjustment in Ahvaz Jundishapur students. Development Strategies in Medical Education. 2015;2(1):26-37.

29- Namdar H, Rahmani A, Ebrahimi H. The Effect of a Skill-Training Model on Nursing Students' Skills in Communicating with Mental Patients. Iranian Journal of Medical Education. 2008;8(2):323-32.

30- Rokni P, Arjomandniya A, Fat'h Abadi J. Investigating the Impact of Social Competence on Improvement of Behavioral Performance of Students with Learning Disorder. Journal of Exceptional Children Empowerment. 2015;15(3):43-53. 